\title{
5' Untranslated Region Mutation
}

National Cancer Institute

\section{Source}

National Cancer Institute. 5' Untranslated Region Mutation. NCI Thesaurus. Code C63432.

Any mutation in a gene occurring in the 5 ' end which contains sequences which may regulate the transcription or translation of the message. 5' UTR mutations are found only outside of open-reading frames. 